\title{
Arthropods associated with young orchard of pecan in southern Brazil
}

\section{Artrópodes associados a um plantio jovem de nogueira-pecã no sul do Brasil}

\author{
Jardel Boscardin 1* (1) (orcid.org/0000-0001-6862-8345) \\ Ervandil Côrrea Costa ${ }^{2}$ (1) (orcid.org/0000-0001-7348-8826) \\ Marciane Danniela Fleck ${ }^{2}$ (1) (orcid.org/0000-0001-7783-7907) \\ Jéssica Maus da Silva2 (10) (orcid.org/0000-0003-4564-0389) \\ Karine Schoeninger ${ }^{3}$ (1) (orcid.org/0000-0001-9079-9570) \\ Jacques Hubert Charles Delabie ${ }^{4}$ (1) (orcid.org/0000-0002-2695-1061)
}

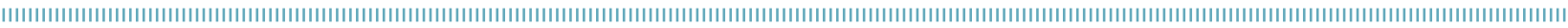

\begin{abstract}
World production of pecan Carya illinoinensis (Juglandaceae) is led by the United States. In Brazil, especially in the Rio Grande do Sul State, there has been an expansion of the planted area in recent years. Despite this expansion of pecan culture, there is a lack of research on entomofauna associated with pecan and on cultural practices which aids in Integrated Pest Management. This study aimed to evaluate the arthropod fauna in the canopies of $C$. illinoinensis trees grown under different soil management practices in Santa Maria, Rio Grande do Sul, Brazil. A randomized design was used with five blocks and four treatments: planting in small pits of $20 \times 60 \mathrm{~cm}(\mathrm{Sp})$ using a subsoiler with a leveling grader/shank, planting in small pits (Ssp) using a rotary tiller (Tsp), and planting in large pits of $40 \times 60 \mathrm{~cm}$ (Lp). A total of 7,617 specimens were collected from November 2014 to May 2015 from the young pecan canopies. Among the 150 taxonomic groups identified, Coleoptera was the most taxonomically rich order. The blackmargined aphid Monellia caryella (Hemiptera: Aphididae) had the greatest abundance. Hymenopteran parasitoids and Coccinellidae spp. were among the natural pest enemies detected. We conclude that the arthropod fauna found in the young pecan canopies is similarly diverse among the different soil managements, with a predominance of pest species $M$. caryella in all the evaluated areas.
\end{abstract}

KEYWORDS: Carya illinoinensis; forest entomology; integrated pest management; Monellia caryella.
RESUMO: A produção mundial de noz-pecã Carya illinoinensis (Juglandaceae) é liderada pelos Estados Unidos. No Brasil, em especial no Rio Grande do Sul, houve uma expansão da área plantada com a cultura nos últimos anos. No entanto, faltam pesquisas relacionadas à entomofauna associada à noz-pecá, bem como práticas culturais que auxiliem no Manejo Integrado de Pragas, mesmo havendo uma expansão da cultura. Assim, o presente estudo objetivou avaliar a fauna de artrópodes na copa de plantas de $C$. illinoinensis, submetido a diferentes manejos de solo, em Santa Maria, Rio Grande do Sul, Brasil. Para tanto, utilizou-se delineamento experimental de blocos ao acaso, com cinco blocos e quatro tratamentos: plantio em cova pequena, com $20 \times 60 \mathrm{~cm}(\mathrm{Sp})$; utilizaçáo de subsolador mais grade niveladora e cova pequena (Ssp); utilizaçáo de enxada rotativa e cova pequena (Tsp); e plantio em cova grande, com $40 \times 60 \mathrm{~cm}$ (Lp). De novembro de 2014 a maio de 2015, foram coletadas 7.617 espécimes nas copas de árvores jovens de nogueira-pecá. Foram identificados 150 grupos taxonômicos, sendo Coleoptera a ordem com maior riqueza de espécies. Monellia caryella (Hemiptera: Aphididae) apresentou elevada densidade. Foram registrados os inimigos naturais himenópteros parasitoides e Coccinellidae. Conclui-se que a artropodofauna em copas de plantas jovens de nogueira-pecã apresenta diversidade similar entre os tratamentos e predomínio de $M$. caryella nas áreas avaliadas.

PALAVRAS-CHAVE: Carya illinoinensis; entomologia florestal; manejo integrado de pragas; Monellia caryella.

\footnotetext{
'Instituto de Ciências Agrárias, Universidade Federal de Uberlândia - Monte Carmelo (MG), Brazil

${ }^{2}$ Programa de Pós-graduação em Engenharia Florestal, Universidade Federal de Santa Maria - Santa Maria (RS), Brazil

${ }^{3}$ Universidade de Santa Cruz do Sul - Santa Cruz do Sul (RS), Brazil

${ }^{4}$ Comissão Executiva do Plano da Lavoura Cacaueira, Centro de Pesquisas do Cacau - Itabuna (BA), Brazil

*Corresponding author: jardel.boscardin@ufu.br

Received on: 05/20/2019. Accepted on: 04/01/2020.
} 


\section{INTRODUCTION}

The world production of pecan Carya illinoinensis (Wangenh.) K. Koch (Juglandaceae) has been led by the United States with 277.4 million pounds of nuts harvested in 2017; 246.1 million pounds $(88.7 \%)$ is from orchards of improved varieties, while the remaining 31.3 million pounds (11.3\%) comes from native plantations (HONIG, 2017). In Brazil, the state of Rio Grande do Sul (RS) has had expansion of areas cultivated with pecan in recent years (BILHARVA et al., 2018), with a planted area of 2,554 hectares, corresponding to $65.9 \%$ of the total productive area of pecan nuts (dried fruit) in the country (IBGE, 2018).

Favorable environmental conditions for pecan cultivation mean that the crop which has been introduced in Brazil has a potential for development in Rio Grande do Sul (ROVANI; WOLLMANN, 2018). There are positive prospects for the implementation of pecan cultivation, mainly due to the nutritional properties of its nut and the medium-term return on investment for farmers (FRONZA et al., 2018).

With the increase of areas planted with pecan in Brazil, there has been growing concern on pest outbreaks, which may damage the crop. It is noteworthy that of the 56 pest species reported in pecans in North America (THOMPSON; CONNER, 2012), the majority (78.5\%) are found in the tree canopy, causing damage to thin branches, leaves or nuts.

Natural enemies, which can also be found in the canopy, are associated with the pest species. For this reason, canopy arthropod surveys are important to delineate proposals for Integrated Pest Management for pecans. Considering that the establishment and development of pecan seedlings is a decisive step toward obtaining good crop productivity, the success of the enterprise is dependent, among other practices, on proper soil management. Pecan plants should be grown on deep, well-drained, soils (CALL et al., 2006).

In addition, soil should be prepared up to three months before planting, while prioritizing soil analysis to address chemical deficiencies, especially $\mathrm{pH}$ and phosphorus (MARTINS et al., 2017). When liming and phosphate applications are needed, they should be carried out 90 days before planting along with deep ploughing $(30 \mathrm{~cm})$ and ground harrowing (MARTINS et al., 2017). The root seedling size at transplanting must be taken into account when choosing the depth of the pits (BOSCARDIN et al., 2017).

The aim of this study was: (a) to evaluate the diversity of crown arthropods in a young pecan orchard and its relationship with the different soil management practices in Santa Maria, Rio Grande do Sul; and (b) to verify the presence of harmful insects and their potential predators and parasitoids.

\section{MATERIAL AND METHODS}

The experiment was conducted in Departamento de Diagnóstico e Pesquisa Agropecuária (DDPA) in Rio Grande do Sul $\left(29^{\circ} 40^{\prime} 31^{\prime \prime} S\right.$; 535 ' $\left.45^{\prime \prime} \mathrm{W}\right)$, located in Santa Maria. The municipality is located in the state's Central Depression region, at an average altitude of 113 meters (m). According to the Köppen classification, the climate of the region is subtropical humid and without droughts (ALVARES et al., 2013). The soil of the study region is classified as a well-drained Arsenic Dystrophic Red Argisol, presenting a Bt (red textural type B) horizon with acidic sandy loam and low organic matter content (STRECK et al., 2008).

Experimental installation area is predominantly covered with short grass species (Poaceae) and shrubs (Baccharis sp. Asteraceae). Before the establishment of the treatments, chemical clearing was carried out in the whole area with application of the herbicide glyphosate and control of leaf-cutting ants with the use of granulated baits in every area of the plantation and its adjacent areas. The adjacent areas are composed of plantations of Eucalyptus spp., Pinus spp. and secondary vegetation species.

Fertilization was carried out in three steps: the first dose was of $200 \mathrm{~g}$ of NPK fertiliser with a formula of $5-20-20$ and $300 \mathrm{~g}$ of dolomitic limestone during the transplantation of pecan seedlings, which was incorporated into the soil and into the pit. Thirty days after planting, the seedlings received another dose of NPK fertilizer using the same formula and amount. Sixty days after planting, the seedlings received $20 \mathrm{~g}$ of urea $(42 \% \mathrm{~N})$ every 60 days.

Treatments were distributed according to a randomized block design with five blocks and four treatments as follow: planting in small circular pits of $20 \mathrm{~cm}$ in diameter and $60 \mathrm{~cm}$ in depth using a drill bit attached to a chainsaw to open the small pits (Sp); planting using a subsoiler with a leveling grader/shank in small circular pits of $20 \mathrm{~cm}$ in diameter and $60 \mathrm{~cm}$ in depth, in which the subsoiling was performed at a depth of $40 \mathrm{~cm}$ using a drill bit attached to a chainsaw to open the small pits (Ssp); planting using a rotary tiller at a depth of approximately $20 \mathrm{~cm}$ and small pits of $20 \mathrm{~cm}$ in diameter and $60 \mathrm{~cm}$ in depth using a drill bit attached to a chainsaw to open the small pits (Tsp); planting in a large circular pit of $40 \mathrm{~cm}$ in diameter and $60 \mathrm{~cm}$ in depth, using a mechanical auger drill coupled to a tractor to open the large pits (Lp).

The treatments were randomly assigned and distributed across the five blocks in $28 \times 21 \mathrm{~m}$ plots $\left(588 \mathrm{~m}^{2}\right)$ for a total area of $11,760 \mathrm{~m}^{2}$. Each parcel had $7 \times 7 \mathrm{~m}$ spacing (lines of $7 \mathrm{~m}$ in length with $7 \mathrm{~m}$ between the lines) and had 12 pecan plants, totaling 240 plants over the entire area. The seedlings used for planting were "Barton" and "Shawnee" cultivars which had a standard height of $60 \mathrm{~cm}$ and were 2.5 years old when transplanted. The seedlings were transplanted on February 12 and 13, 2012.

In February 2015, physical soil analysis was performed for the evaluated areas in order to document any differences in soils that may influence study results. The analysis included percentage of clay, soil density, macroporosity, microporosity and total porosity of the soil at depths from $0.0-0.10 \mathrm{~m}$. In the same month, chemical soil analyses of hydrogen ionic 
potential $(\mathrm{pH})$, micronutrients $(\mathrm{B}, \mathrm{Cu}$ and $\mathrm{Zn})$, and macronutrients (P, S, K, $\mathrm{Al}, \mathrm{Ca}$ and $\mathrm{Mg}$ ) were performed, and the organic matter $(\mathrm{OM})$ in the different areas evaluated was verified.

For the soil physical and chemical properties, as well as organic matter, there were no significant differences (ANOVA, $\mathrm{p} \geq 0.05$ ) between the means found for the different soil managements for pecan (Tables 1 and 2). Thus, considering such parameters, the sampling areas were determined to be homogeneous.

Table 1. Percentage of clay, soil density, macroporosity, microporosity and total soil porosity at depths from $0.0-0.10 \mathrm{~m}$ in a young pecan orchard with different soil managements. February 2015, in Santa Maria, Rio Grande do Sul, Brazil.

\begin{tabular}{|c|c|c|c|c|c|}
\hline \multirow{2}{*}{ Treatments } & \multirow{2}{*}{$\begin{array}{l}\text { Clay } \\
\text { (\%) }\end{array}$} & \multirow{2}{*}{$\begin{array}{c}\text { Soil } \\
\text { Density } \\
\left(\mathrm{g} \mathrm{cm}^{-3}\right)\end{array}$} & \multicolumn{3}{|c|}{ Porosity $\left(\mathrm{cm}^{3} \mathrm{~cm}^{-3}\right)$} \\
\hline & & & Macro & Micro & Total \\
\hline Sp & $17.3^{a}$ & $1.57^{\mathrm{a}}$ & $0.16^{a}$ & $0.25^{a}$ & $0.40^{a}$ \\
\hline Ssp & $16.8^{a}$ & $1.53^{a}$ & $0.15^{a}$ & $0.27^{a}$ & $0.42^{a}$ \\
\hline Tsp & $17.6^{a}$ & $1.46^{\mathrm{a}}$ & $0.21^{a}$ & $0.25^{a}$ & $0.46^{a}$ \\
\hline Lp & $17.8^{a}$ & $1.61^{\mathrm{a}}$ & $0.14^{a}$ & $0.28^{a}$ & $0.42^{a}$ \\
\hline CV(\%) & 7.3 & 6.2 & 11.6 & 9.1 & 7.7 \\
\hline
\end{tabular}

Treatments: Sp - planting in small pits $(20 \times 60 \mathrm{~cm})$, Ssp - using a subsoiler with a levelling grader/shank and small pits, Tsp using a rotary tiller and small pits, and $L p$ - planting in large pits $(40 \times 60 \mathrm{~cm})$. Means within the same column followed by the same capital letter do not differ by Tukey's test at $5 \%$ significance $(n=20)$.

Table 2. Organic matter (OM), hydrogenation potential $(\mathrm{pH})$, micronutrients (B, Cu and Zn) and macronutrients (P, S, K, Al, Ca and $\mathrm{Mg}$ ) in a young pecan orchard under different soil managements. February 2015, in Santa Maria, Rio Grande do Sul, Brazil

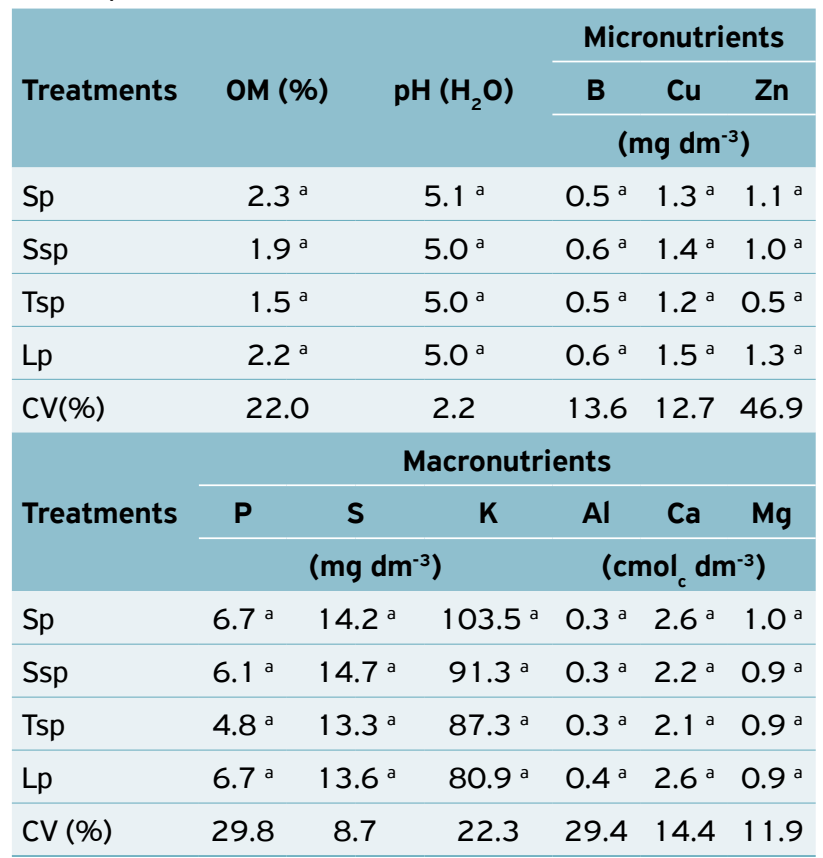

Treatments: $\mathrm{Sp}$ - planting in small pits $(20 \times 60 \mathrm{~cm})$, Ssp - using a subsoiler with a levelling grader/shank and small pits, Tsp - using a rotary tiller and small pits, and Lp - planting in large pits $(40 \times 60$ $\mathrm{cm})$. Means within a column followed by the same capital letter do not differ by Tukey's test at $5 \%$ significance $(n=20)$.
For the arthropod survey, the canopy network (adapted insect net) methodology was used, consisting of a ring of $40 \mathrm{~cm}$ in diameter and an $80 \mathrm{~cm}$ long tapering cotton cloth bag, with the rounded end containing a cable (GALLO et al., 2002). A ladder was used to reach the canopy of the plant. After the sack of the net was wrapped in the branches of the plants, there were five shakes in branches localizaded in each cardinal direction, north, south, west and east. From November 13, 2014 to May 20, 2015, 13 collections of crown arthropods were performed every 15 20 days. This corresponds to the vegetative growth period of the trees when they have leaves in the canopy. The collections were carried out on the same four pecan trees per treatment in each block, totaling 80 trees sampled for each date of collection and 1,040 samples throughout the sampling period.

Collections were carried out in the morning, between 9 a.m. and 12 p.m. on four similar trees, with similar height and diameter measurements. All trees sampled were measured in March 2015; the mean height was $2.9 \pm 0.6 \mathrm{~m}$, and the mean diameter was $39.1 \pm 9.3 \mathrm{~mm}$.

After collection, the material was taken to the laboratory and kept in refrigeration (approximately $-6^{\circ} \mathrm{C}$ ) until the time of sorting. Morphospecies were identified and coded by the first author and then referred to specialists in the relevant taxonomic areas for identification to species.

Analysis of variance (ANOVA) at 5\% probability of error was performed for soil physical and chemical properties. The ecological parameters analyzed were relative frequency (\%) and richness $(S)$. The relative frequency was calculated according to the formula: $\mathrm{F} \%=\mathrm{N} / \mathrm{Nt} \times 100$, in which: $\mathrm{F} \%=$ relative frequency, $\mathrm{N}=$ total number of individuals of each taxon, and $\mathrm{Nt}=$ total of individuals captured. In order to assess diversity, the Shannon Diversity Index $(H)$ was calculated. As a measure of heterogeneity, this index considers the degree of uniformity, also called the Uniformity or Pielou equitability index $(J)$.

In order to verify the possible differences between abundance and species richness of the crown arthropod fauna collected from pecan trees, analysis of variance (ANOVA) at $5 \%$ probability of error was performed for richness and abundance data under different soil managements. The Shapiro-Wilk normality test was applied, and the abundance data were transformed into $x^{c}=\log (\log x)$ to meet the requirements of the descriptive statistics. All the statistical analyses and the ecological parameters in the present study were performed using the R program, version 3.3.1 (R DEVELOPMENT CORE TEAM, 2016).

\section{RESULTS}

In the period from November 13, 2014 to May 20, 2015, 7,617 arthropod specimens were collected from the pecan canopy and distributed among 150 taxonomic groups. Insects had the highest observed richness $(S=136)$ and abundance, 
with $96.7 \%$ of the total catch $(7,365$ individuals), followed by Arachnida $(S=12)$, with $3.25 \%$ (248 individuals), and Entognatha $(S=2)$, with only $0.05 \%$ (4 individuals) (Table 3 ).

In relation to the values of the Shannon diversity indexes and the Pielou evenness, the treatment values were similar to each other. The high richness and uniformity in the species distribution found in the total and evaluated areas justified the occurrence of high index values (Table 3). There was no statistical difference between the means of species richness and abundance (ANOVA, $\mathrm{p}>0.05$ ) of canopy arthropods collected in evaluated treatment areas. Therefore, the area may be considered homogeneous. Moreover, the arthropod fauna associated with the pecan tree canopies is not affected by the different soil managements.

Among all the species found in the pecan canopies, $44(29.3 \%)$ occurred in all three seasons corresponding to vegetative growth: spring, summer and fall. Twenty-five species $(16.7 \%)$ were exclusively collected in summer; 21 (14.0\%) were collected in both spring and summer; 17 (11.3\%) were exclusively collected in spring; $17(11.3 \%)$ were collected in the spring and fall; 15 (10.0\%) were exclusively collected in fall; and 11 taxonomic groups (7.3\%) were collected in both the summer and fall (Table 3 ).

The highest number of species was collected during the summer of 2015, which presented the highest average and minimum temperatures. Hence, 101 (67.3\%) species were collected in the summer, followed by 99 (66.0\%) species collected in the spring and $87(58.0 \%)$ species collected in the fall (Table 3).

During the course of this study, possible predator-prey population interactions were documented. The introduced ladybug Harmonia axyridis (Pallas) (Coleoptera: Coccinellidae) had a higher population density (77 individuals) on May 6, 2015. The blackmargined aphid Monellia caryella (Fitch) (Hemiptera: Aphididae), an introduced pest species of pecan in Brazil, had the greatest abundance, with 225 specimens collected on February 23, 2015 (Fig. 1). The population pressure of the blackmargined aphid may have caused an increase in the population of $H$. axyridis (Fig. 1).

\section{DISCUSSION}

Blackmargined aphid M. caryella is one of the main insect pests of pecan that is endemic to the native range of $C$. illinoinensis, from Mexico to Illinois in the United States (THOMPSON; CONNER, 2012). The presence of the insect, which was approximately $10 \%$ of the total number of pecan canopy arthropods collected for our study, indicates the species' adaptability and the potential risk of infestation in Brazil. Both the adult and immature blackmargined aphids consume the sap, mainly in the abaxial part of the leaf, and excrete a sweet and sticky substance known as "honeydew". Feeding by high populations of aphids can damage the vascular system of the leaves and remove nutrients from the plants. The "honeydew" that covers the leaves favors the growth of sooty mold, which interferes in the photosynthetic capacity of the leaf (REE; KNUTSON, 1997). Chrysoperla rufilabris (Chrysopidae) and Olla v-nigrum (Mulsant) (Coccinellidae) have been reported to consume 2560 aphids M. caryella per day (LIAO et al., 1985).

In this study, the class Arachnida was represented by spiders, which are potential predators of pecan insect pests. In a previous survey carried out in a pecan orchard in Texas, 25 species of Araneae were identified. Studies indicate a density of $10-100$ spiders per leaf and less than $1-10$ specimens of the M. caryella (BUMROONGSOOK et al., 1992). Thus, the spiders are important predators acting as a natural biological control of $M$. caryella.

Among the potential pests observed in the present study, one highlight is the presence of phyllophagous species belonging to the order Coleoptera, which are harmful leaf strippers such as Diabrotica speciosa (Germar) (Chrysomelidae). This species has already been a registered pest for pecan in Brazil (BOSCARDIN; COSTA, 2018).

For the order Hemiptera, the species Oncometopia facialis (Signoret) (Cicadellidae) belonging to the suborder Auchenorrhyncha was present and may be associated with the transmission of the pathogenic bacterium Xylella fastidiosa in citrus (GALLO et al., 2002). For the true bug group (Heteroptera), the seven species found were in the family Pentatomidae: Dichelops (Diceraeus) furcatus (Fabricius), Edessa meditabunda (Fabricius), Euschistus (Euschistus) heros (Fabricius), and Piezodorus guildinii (Westwood). These species are considered pests of soybeans (GALLO et al., 2002). Loxa deducta (Walker) has already been found attacking pecan nuts in Rio Grande do Sul, Brazil (BOSCARDIN et al., 2016).

Furthermore, various psyllids (Hemiptera: Psylloidea) were found on pecan plants from the treatment areas. They are found in eucalyptus such as Blastopsylla occidentalis (Taylor), Ctenarytaina spatulata (Taylor) and Glycaspis brimblecombei (Moore), which are eucalyptus pests (BURCKHARDT et al., 1999). Their presence can be explained by the Eucalyptus sp. plantations in the area surrounding the pecans. Adults of psyllids have been found on pecan plants in investigated areas. As they are not immatures, pecan is not host (BURCKHARDT et al., 2014).

The leaf-cutting ant Atta sexdens (Linnaeus) (Hymenoptera: Formicidae) was collected in pecan plots where some injuries to trees were verified; however, they were not quantified. Leafcutting ants can cause damage, especially in the establishment phase of pecan orchards in Brazil (MARTINS et al., 2017).

The order Orthoptera was represented with three phytophagous families: Acrididae, Proscopiidae and Tettigoniidae. For these insects, there is a record of defoliation in eucalyptus seedlings caused by Tetanorhynchus smithi (Rehn) (Proscopiidae) (SANTOS et al., 2015). 
Table 3. Absolute and relative frequencies (\%) of arthropods collected from the canopies of young pecan orchards with different soil managements in Santa Maria, Rio Grande do Sul, Brazil. November 2014 - May 2015.

\begin{tabular}{|c|c|c|c|c|c|}
\hline \multirow{2}{*}{ Taxonomic Groups } & \multicolumn{4}{|c|}{ Soil management } & \multirow{2}{*}{ Total } \\
\hline & Sp & Ssp & Tsp & Lp & \\
\hline \multicolumn{6}{|l|}{ CLASS ARACHNIDA } \\
\hline \multicolumn{6}{|l|}{ Order Araneae } \\
\hline \multicolumn{6}{|l|}{ Family Anyphaenidae } \\
\hline Arachosia honesta Eugen von Keyserling ${ }^{(2)(3)(4)}$ & $4(0.2)$ & $5(0.2)$ & $2(0.1)$ & $2(0.1)$ & $13(0.2)$ \\
\hline Xiruana hirsuta (Mello-Leitão) $)^{(2)(3)(4)}$ & $2(0.1)$ & $1(<0.1)$ & - & - & $3(<0.1)$ \\
\hline Anyphaenidae sp. $1^{(2)(3)}$ & $2(0.1)$ & - & $1(0.1)$ & $2(0.1)$ & $5(0.1)$ \\
\hline \multicolumn{6}{|l|}{ Family Araneidae } \\
\hline Araneus corporosus (Eugen von Keyserling)(2)(3)(4) & - & $2(0.1)$ & $1(0.1)$ & - & $3(<0.1)$ \\
\hline Eustala sp..$^{(3)(4)}$ & $1(0.1)$ & $1(<0.1)$ & $1(0.1)$ & - & $3(<0.1)$ \\
\hline \multicolumn{6}{|l|}{ Family Eutichuridae } \\
\hline Cheiracanthium inclusum (Hentz) $)^{(2)(3)(4)}$ & $8(0.4)$ & $9(0.4)$ & $12(0.7)$ & $16(0.9)$ & $45(0.6)$ \\
\hline Family Salticidae ${ }^{(2)(3)(4)}$ & $46(2.4)$ & 39 (1.9) & $33(1.8)$ & $39(2.1)$ & $157(2.1)$ \\
\hline Family Sparassidae ${ }^{(3)(4)}$ & $3(0.2)$ & $1(<0.1)$ & $1(0.1)$ & $2(0.1)$ & $7(0.1)$ \\
\hline \multicolumn{6}{|l|}{ Family Theridiidae } \\
\hline Anelosinus inbandava Agnarsson ${ }^{(3)}$ & - & $1(<0.1)$ & - & - & $1(<0.1)$ \\
\hline \multicolumn{6}{|l|}{ Family Thomisidae } \\
\hline Misumenops sp. ${ }^{(2)(4)}$ & - & $3(0.1)$ & $1(0.1)$ & $4(0.2)$ & $8(0.1)$ \\
\hline \multicolumn{6}{|l|}{ Order Sarcoptiformes } \\
\hline Suborder Oribatida ${ }^{(2)}$ & - & - & - & $1(0.1)$ & $1(<0.1)$ \\
\hline \multicolumn{6}{|l|}{ Order Trombidiformes } \\
\hline Family Erythraeidae (immatures) ${ }^{(4)}$ & $2(0.1)$ & - & - & - & $2(<0.1)$ \\
\hline \multicolumn{6}{|l|}{ CLASS ENTOGNATHA } \\
\hline \multicolumn{6}{|l|}{ Order Entomobryomorpha } \\
\hline Family Entomobryidae ${ }^{(3)}$ & - & $1(<0.1)$ & - & - & $1(<0.1)$ \\
\hline Order Symphypleona ${ }^{(4)}$ & $1(0.1)$ & - & - & $2(0.1)$ & $3(<0.1)$ \\
\hline \multicolumn{6}{|l|}{ CLASS INSECTA } \\
\hline Order Blattodea ${ }^{(3)(4)}$ & $5(0.3)$ & $2(0.1)$ & $2(0.1)$ & $2(0.1)$ & $11(0.1)$ \\
\hline \multicolumn{6}{|l|}{ Order Coleoptera } \\
\hline \multicolumn{6}{|l|}{ Family Anthicidae } \\
\hline Acanthinus sp. $3^{(2)(3)(4)}$ & $9(0.5)$ & $10(0.5)$ & $5(0.3)$ & $10(0.5)$ & $34(0.4)$ \\
\hline \multicolumn{6}{|l|}{ Family Brachyderidae } \\
\hline Erirrhininae $\mathrm{sp} .3^{(2)(3)}$ & - & $13(0.6)$ & - & $3(0.2)$ & $16(0.2)$ \\
\hline \multicolumn{6}{|l|}{ Family Brentidae } \\
\hline Apion sp. $1^{(3)(4)}$ & $1(0.1)$ & $2(0.1)$ & $3(0.2)$ & $2(0.1)$ & $8(0.1)$ \\
\hline \multicolumn{6}{|l|}{ Family Buprestidae } \\
\hline Agrilus sp. $1^{(3)(4)}$ & $4(0.2)$ & $1(<0.1)$ & $1(0.1)$ & - & $6(0.1)$ \\
\hline Pachyschelus sp. $1^{(3)}$ & $1(0.1)$ & - & $1(0.1)$ & - & $2(<0.1)$ \\
\hline \multicolumn{6}{|l|}{ Family Cantharidae } \\
\hline Chauliognathus expansus (Waterh) ${ }^{(2)(3)}$ & $2(0.1)$ & - & - & $1(0.1)$ & $3(<0.1)$ \\
\hline Chauliognathus fallax Germar ${ }^{(2)(3)}$ & $155(8.2)$ & $72(3.5)$ & $127(7.0)$ & $78(4.2)$ & $432(5.7)$ \\
\hline Chauliognathus flavipes Fabricius ${ }^{(2)(3)}$ & $68(3.6)$ & $92(4.5)$ & $65(3.6)$ & $84(4.5)$ & $309(4.1)$ \\
\hline Chauliognathus sp. $1^{(2)(3)(4)}$ & $28(1.5)$ & $47(2.3)$ & $62(3.4)$ & $7(0.4)$ & $144(1.9)$ \\
\hline Discodon tucumanum $\mathrm{Pic}^{(2)(3)(4)}$ & $8(0.4)$ & $20(1.0)$ & $7(0.4)$ & $7(0.4)$ & $42(0.6)$ \\
\hline
\end{tabular}


Table 3. Continuation.

\begin{tabular}{|c|c|c|c|c|c|}
\hline \multirow{2}{*}{ Taxonomic Groups } & \multicolumn{4}{|c|}{ Soil management } & \multirow{2}{*}{ Total } \\
\hline & Sp & Ssp & Tsp & Lp & \\
\hline Discodon sp. $1^{(3)(4)}$ & $1(0.1)$ & - & - & $1(0.1)$ & $2(<0.1)$ \\
\hline Discodon sp. $2^{(4)}$ & $1(0.1)$ & - & $1(0.1)$ & $1(0.1)$ & $3(<0.1)$ \\
\hline Silis sp. $1^{(2)(3)}$ & - & - & $1(0.1)$ & $3(0.2)$ & $4(0.1)$ \\
\hline \multicolumn{6}{|l|}{ Family Cerambycidae } \\
\hline Hippopsis sp. $1^{(2)}$ & - & $1(<0.1)$ & - & - & $1(<0.1)$ \\
\hline \multicolumn{6}{|l|}{ Family Chelonariidae } \\
\hline Chelonarium sp. $1^{(3)}$ & $1(0.1)$ & - & - & - & $1(<0.1)$ \\
\hline \multicolumn{6}{|l|}{ Family Chrysomelidae } \\
\hline Acalymma sp. $1^{(4)}$ & - & $1(<0.1)$ & - & - & $1(<0.1)$ \\
\hline Cacoscelis sp. $1^{(2)}$ & - & - & - & $1(0.1)$ & $1(<0.1)$ \\
\hline Costalimaita ferruginea (Fabricius) ${ }^{(2)}$ & - & - & - & $1(0.1)$ & $1(<0.1)$ \\
\hline Diabrotica speciosa (Germar)(2)(3)(4) & $3(0.2)$ & $12(0.6)$ & $3(0.2)$ & $7(0.4)$ & $25(0.3)$ \\
\hline Disonycha sp. $1^{(2)}$ & - & - & - & $1(0.1)$ & $1(<0.1)$ \\
\hline Lexiphanes sp. $1^{(2)(3)(4)}$ & $6(0.3)$ & $23(1.1)$ & $18(1.0)$ & $18(1.0)$ & $65(0.9)$ \\
\hline Lexiphanes sp..$^{(3)}$ & $2(0.1)$ & $2(0.1)$ & - & - & $4(0.1)$ \\
\hline Parabrotica sp. $1^{(2)}$ & $1(0.1)$ & - & - & - & $1(<0.1)$ \\
\hline Parabrotica sp. $2^{(2)}$ & $1(0.1)$ & - & - & - & $1(<0.1)$ \\
\hline Eumolpini sp. $2^{(2)(3)}$ & $4(0.2)$ & - & $8(0.4)$ & - & $12(0.2)$ \\
\hline \multicolumn{6}{|l|}{ Family Coccinellidae } \\
\hline Cycloneda sanguinea (Linnaeus) $)^{(2)(3)(4)}$ & $22(1.2)$ & $29(1.4)$ & $29(1.6)$ & $14(0.8)$ & $94(1.2)$ \\
\hline Harmonia axyridis (Pallas) ${ }^{(2)(3)(4)}$ & $76(4.0)$ & $98(4.8)$ & $94(5.2)$ & $87(4.7)$ & $355(4.7)$ \\
\hline Harmonia sp. $1^{(2)(3)(4)}$ & $31(1.6)$ & $27(1.3)$ & $22(1.2)$ & $26(1.4)$ & $106(1.4)$ \\
\hline Hyperaspis sp. $1^{(3)}$ & - & - & - & $1(0.1)$ & $1(<0.1)$ \\
\hline Scymnus sp. $1^{(4)}$ & $7(0.4)$ & $9(0.4)$ & $2(0.1)$ & $5(0.3)$ & $23(0.3)$ \\
\hline \multicolumn{6}{|l|}{ Family Curculionidae } \\
\hline Heilipus sp. $1^{(3)}$ & - & - & - & $1(0.1)$ & $1(<0.1)$ \\
\hline Lobaspis squamosus (Boheman)(2)(3) & - & - & $1(0.1)$ & - & $1(<0.1)$ \\
\hline Pantomorus sp. $1^{(4)}$ & $5(0.3)$ & - & $2(0.1)$ & $3(0.2)$ & $10(0.1)$ \\
\hline Eudiagogini sp. $1^{(2)(3)(4)}$ & $2(0.1)$ & $1(<0.1)$ & - & - & $3(<0.1)$ \\
\hline \multicolumn{6}{|l|}{ Family Elateridae } \\
\hline Conoderus sp. $1^{(3)(4)}$ & $2(0.1)$ & - & $2(0.1)$ & $2(0.1)$ & $6(0.1)$ \\
\hline Family Erotylidae ${ }^{(2)(3)}$ & - & $1(<0.1)$ & - & $1(0.1)$ & $2(<0.1)$ \\
\hline \multicolumn{6}{|l|}{ Family Lampyridae } \\
\hline Aspisoma maculata (Degeer) ${ }^{(3)(4)}$ & $3(0.2)$ & $2(0.1)$ & $1(0.1)$ & $2(0.1)$ & $8(0.1)$ \\
\hline Aspisoma sp. $1^{(2)(3)}$ & $5(0.3)$ & $4(0.2)$ & $3(0.2)$ & $3(0.2)$ & $15(0.2)$ \\
\hline Cratomorphus sp. $1^{(2)(3)}$ & $2(0.1)$ & - & - & - & $2(<0.1)$ \\
\hline Lucidota sp. $1^{(3)}$ & - & - & $1(0.1)$ & - & $1(<0.1)$ \\
\hline Pyrogaster sp. $1^{(3)}$ & - & - & - & $1(0.1)$ & $1(<0.1)$ \\
\hline \multicolumn{6}{|l|}{ Family Latridiidae } \\
\hline Melanophthalma sp. $1^{(2)}$ & - & $1(<0.1)$ & - & $2(0.1)$ & $3(<0.1)$ \\
\hline \multicolumn{6}{|l|}{ Family Lycidae } \\
\hline Haplobothris sp. $1^{(2) ;(3)}$ & $1(0.1)$ & $2(0.1)$ & $2(0.1)$ & $2(0.1)$ & $7(0.1)$ \\
\hline \multicolumn{6}{|l|}{ Family Melyridae } \\
\hline Astylus variegatus (Germar)(3) & $1(0.1)$ & - & $1(0.1)$ & $2(0.1)$ & $4(0.1)$ \\
\hline
\end{tabular}


Table 3. Continuation.

\begin{tabular}{|c|c|c|c|c|c|}
\hline \multirow{2}{*}{ Taxonomic Groups } & \multicolumn{4}{|c|}{ Soil management } & \multirow{2}{*}{ Total } \\
\hline & Sp & Ssp & Tsp & Lp & \\
\hline \multicolumn{6}{|l|}{ Family Tenebrionidae } \\
\hline Allecula sp. $1^{(4)}$ & - & - & $1(0.1)$ & - & $1(<0.1)$ \\
\hline Lagria villosa (Fabricius) ${ }^{(3)(4)}$ & $1(0.1)$ & $1(<0.1)$ & - & $7(0.4)$ & $9(0.1)$ \\
\hline Lobopoda sp. $1^{(3)(4)}$ & - & - & - & $2(0.1)$ & $2(<0.1)$ \\
\hline Order Diptera ${ }^{(2)(3)(4)}$ & $232(12.3)$ & $255(12.4)$ & $172(9.5)$ & $293(15.8)$ & $952(12.5)$ \\
\hline \multicolumn{6}{|l|}{ Family Bibionidae } \\
\hline Plecia cf. nearctica Hardy ${ }^{(3)(4)}$ & $45(2.4)$ & $91(4.4)$ & $77(4.2)$ & $60(3.2)$ & $273(3.6)$ \\
\hline \multicolumn{6}{|l|}{ Order Hemiptera } \\
\hline \multicolumn{6}{|l|}{ Suborder Auchenorrhyncha } \\
\hline \multicolumn{6}{|l|}{ Family Cicadellidae } \\
\hline Bucephalogonia xanthophis (Berg) $)^{(2)(3)(4)}$ & $52(2.7)$ & $43(2.1)$ & $44(2.4)$ & $46(2.5)$ & $185(2.4)$ \\
\hline Gypona sp. $1^{(2)(4)}$ & $1(0.1)$ & - & - & $1(0.1)$ & $2(<0.1)$ \\
\hline Oncometopia facialis (Signoret) $)^{(2)}$ & - & - & $1(0.1)$ & - & $1(<0.1)$ \\
\hline Cicadellidae sp. $1^{(2)}$ & - & $1(<0.1)$ & - & - & $1(<0.1)$ \\
\hline \multicolumn{6}{|l|}{ Family Cicadidae } \\
\hline Cicadidae sp. $1^{(2)(3)(4)}$ & $2(0.1)$ & $3(0.1)$ & $3(0.2)$ & - & $8(0.1)$ \\
\hline Family Derbidae ${ }^{(2)(3)(4)}$ & $65(3.4)$ & $71(3.5)$ & $98(5.4)$ & $66(3.5)$ & $300(3.9)$ \\
\hline Family Dictyopharidae sp. $1^{(3)}$ & $4(0.2)$ & $1(<0.1)$ & $1(0.1)$ & - & $6(0.1)$ \\
\hline Family Flatidae ${ }^{(2)(4)}$ & - & $1(<0.1)$ & $2(0.1)$ & - & $3(<0.1)$ \\
\hline \multicolumn{6}{|l|}{ Family Membracidae } \\
\hline Ceresa stylata Remes-Lenicov(2) & - & $1(<0.1)$ & - & - & $1(<0.1)$ \\
\hline Ceresa ustulata Fairmaire ${ }^{(2)(3)(4)}$ & $42(2.2)$ & $34(1.7)$ & $36(2.0)$ & $36(1.9)$ & $148(1.9)$ \\
\hline Hypsoprora erecta Fonseca ${ }^{(2)(3)(4)}$ & - & - & $2(0.1)$ & $1(0.1)$ & $3(<0.1)$ \\
\hline \multicolumn{6}{|l|}{ Suborder Heteroptera } \\
\hline \multicolumn{6}{|l|}{ Family Anthocoridae } \\
\hline Anthocoridae sp. $1^{(2)}$ & $1(0.1)$ & - & - & - & $1(<0.1)$ \\
\hline Anthocoridae sp. $2^{(3)}$ & - & - & $1(0.1)$ & - & $1(<0.1)$ \\
\hline \multicolumn{6}{|l|}{ Family Coreidae } \\
\hline Althos sp. $1^{(2)}$ & $2(0.1)$ & - & $1(0.1)$ & - & $3(<0.1)$ \\
\hline Family Miridae ${ }^{(2)(3)(4)}$ & $7(0.4)$ & $3(0.1)$ & $2(0.1)$ & $5(0.3)$ & $17(0.2)$ \\
\hline \multicolumn{6}{|l|}{ Family Pentatomidae } \\
\hline Arvelius albopunctatus (De Geer) ${ }^{(4)}$ & - & $1(<0.1)$ & $1(0.1)$ & - & $2(<0.1)$ \\
\hline Banasa cf. derivata (Walker) ${ }^{(2)}$ & - & - & $1(0.1)$ & - & $1(<0.1)$ \\
\hline Dichelops (Diceraeus) furcatus (Fabricius) & $2(0.1)$ & - & $1(0.1)$ & $1(0.1)$ & $4(0.1)$ \\
\hline Edessa meditabunda (Fabricius) $)^{(4)}$ & - & - & $1(0.1)$ & - & $1(0.1)$ \\
\hline Euschistus (Euschistus) heros (Fabricius) ${ }^{(4)}$ & - & - & $1(0.1)$ & - & $1(<0.1)$ \\
\hline Loxa deducta Walker ${ }^{(4)}$ & - & $1(<0.1)$ & - & - & $1(<0.1)$ \\
\hline Piezodorus guildinii (Westwood) ${ }^{(3)}$ & $1(0.1)$ & $1(<0.1)$ & $1(0.1)$ & - & $3(<0.1)$ \\
\hline \multicolumn{6}{|l|}{ Family Reduviidae } \\
\hline Apiomerus sp. $1^{(2)(3)}$ & $1(0.1)$ & $2(0.1)$ & - & $1(0.1)$ & $4(0.1)$ \\
\hline Arilus sp. $1^{(2)}$ & $1(0.1)$ & - & - & - & $1(<0.1)$ \\
\hline Zelus armillatus (Lepeletier \& Serville) $)^{(3)(4)}$ & $36(1.9)$ & $3(0.1)$ & $1(0.1)$ & - & $40(0.5)$ \\
\hline Zelus pedestris Fabricius ${ }^{(2)(3)(4)}$ & $9(0.5)$ & $7(0.3)$ & $6(0.3)$ & $6(0.3)$ & $28(0.4)$ \\
\hline Family Rhyparochromidae ${ }^{(2)(4)}$ & $2(0.1)$ & $2(0.1)$ & $1(0.1)$ & $1(0.1)$ & $6(0.1)$ \\
\hline
\end{tabular}


Table 3. Continuation.

\begin{tabular}{|c|c|c|c|c|c|}
\hline \multirow{2}{*}{ Taxonomic Groups } & \multicolumn{4}{|c|}{ Soil management } & \multirow{2}{*}{ Total } \\
\hline & Sp & Ssp & Tsp & Lp & \\
\hline \multicolumn{6}{|l|}{ Suborder Sternorrhyncha } \\
\hline \multicolumn{6}{|l|}{ Family Aphalaridae } \\
\hline Blastopsylla occidentalis Taylor ${ }^{(2)(3)(4)}$ & $10(0.5)$ & $23(1.1)$ & $4(0.2)$ & $25(1.3)$ & $62(0.8)$ \\
\hline Ctenarytaina spatulata Taylor ${ }^{(2)(3)(4)}$ & - & - & $4(0.2)$ & - & $4(0.1)$ \\
\hline Glycaspis brimblecombei (Moore) ${ }^{(2)(3)}$ & $2(0.1)$ & $7(0.3)$ & $3(0.2)$ & $2(0.1)$ & $14(0.2)$ \\
\hline \multicolumn{6}{|l|}{ Family Aphididae } \\
\hline Monellia caryella (Fitch) $)^{(2)(3)(4)}$ & $155(8.2)$ & $202(9.8)$ & $180(9.9)$ & $201(10.8)$ & $738(9.7)$ \\
\hline Aphididae sp. $1^{(2)(3)(4)}$ & $2(0.1)$ & $2(0.1)$ & $1(0.1)$ & $2(0.1)$ & $7(0.1)$ \\
\hline Aphididae $\mathrm{sp} .2^{(2)(3)(4)}$ & $1(0.1)$ & $5(0.2)$ & - & - & $6(0.1)$ \\
\hline \multicolumn{6}{|l|}{ Family Psyllidae } \\
\hline Heteropsylla sp. ${ }^{(2)(4)}$ & $1(0.1)$ & $3(0.1)$ & $1(0.1)$ & $1(0.1)$ & $6(0.1)$ \\
\hline Mitropsylla sp..$^{(3)}$ & - & $1(<0.1)$ & - & - & $1(<0.1)$ \\
\hline Platycorypha sp. ${ }^{(2)(4)}$ & $2(0.1)$ & $1(<0.1)$ & - & - & $3(<0.1)$ \\
\hline \multicolumn{6}{|l|}{ Family Triozidae } \\
\hline Triozoida cf. angustipennis Burckhardt(3)(4) & - & - & $1(0.1)$ & $1(0.1)$ & $2(<0.1)$ \\
\hline \multicolumn{6}{|l|}{ Order Hymenoptera } \\
\hline \multicolumn{6}{|l|}{ Suborder Apocrita - "Parasitica" } \\
\hline \multicolumn{6}{|l|}{ Family Braconidae } \\
\hline Bracon sp..$^{(2)(3)}$ & - & - & - & $4(0.2)$ & $4(0.1)$ \\
\hline Heterospilus sp..$^{(4)}$ & - & - & - & $1(0.1)$ & $1(<0.1)$ \\
\hline Triaspis sp. ${ }^{(3)}$ & $1(0.1)$ & - & $1(0.1)$ & - & $2(<0.1)$ \\
\hline \multicolumn{6}{|l|}{ Family Chalcididae } \\
\hline Conura sp. ${ }^{(3)}$ & - & $1(<0.1)$ & - & $4(0.2)$ & $5(0.1)$ \\
\hline \multicolumn{6}{|l|}{ Family Encyrtidae } \\
\hline Copidosoma sp. ${ }^{(2)(3)(4)}$ & $11(0.6)$ & $53(2.6)$ & $6(0.3)$ & $3(0.2)$ & $73(1.0)$ \\
\hline \multicolumn{6}{|l|}{ Family Eulophidae } \\
\hline Aprostocetus sp..$^{(2)(3)}$ & - & - & $4(0.2)$ & $1(0.1)$ & $5(0.1)$ \\
\hline Baryscapus sp.(2)(3) & - & $2(0.1)$ & $1(0.1)$ & - & $3(<0.1)$ \\
\hline Euderus sp..$^{(3)}$ & - & $1(<0.1)$ & - & - & $1(<0.1)$ \\
\hline Euplectrus sp..$^{(3)}$ & - & - & $1(0.1)$ & - & $1(<0.1)$ \\
\hline Horismenus sp. $1^{(2)(3)(4)}$ & $11(0.6)$ & $12(0.6)$ & $4(0.2)$ & $8(0.4)$ & $35(0.5)$ \\
\hline Horismenus sp. $2^{(2)}$ & - & - & $1(0.1)$ & $2(0.1)$ & $3(<0.1)$ \\
\hline \multicolumn{6}{|l|}{ Family Eupelmidae } \\
\hline Anastatus sp..$^{(3)(4)}$ & $6(0.3)$ & $8(0.4)$ & $3(0.2)$ & $6(0.3)$ & $23(0.3)$ \\
\hline \multicolumn{6}{|l|}{ Family Eurytomidae } \\
\hline Eurytoma sp..$^{(3)}$ & - & - & - & $1(0.1)$ & $1(<0.1)$ \\
\hline Family Figitidae $(2)$ & - & $1(<0.1)$ & - & - & $1(<0.1)$ \\
\hline \multicolumn{6}{|l|}{ Family Ichneumonidae } \\
\hline Enicospilus sp. ${ }^{(4)}$ & - & $1(<0.1)$ & - & - & $1(<0.1)$ \\
\hline Netelia sp..$^{(4)}$ & $1(0.1)$ & - & - & $1(0.1)$ & $2(<0.1)$ \\
\hline Campopleginae sp..$^{(3)}$ & $14(0.7)$ & $6(0.3)$ & $11(0.6)$ & $6(0.3)$ & $37(0.5)$ \\
\hline \multicolumn{6}{|l|}{ Family Platygastridae } \\
\hline Inostemma striaticornu Buhl(2)(3)(4) & $63(3.3)$ & $106(5.2)$ & $66(3.6)$ & $67(3.6)$ & $302(4.0)$ \\
\hline Telenominae sp..$^{(2)(3)(4)}$ & $20(1.1)$ & $22(1.1)$ & $23(1.3)$ & $22(1.2)$ & $87(1.1)$ \\
\hline
\end{tabular}


Table 3. Continuation.

\begin{tabular}{|c|c|c|c|c|c|}
\hline \multirow{2}{*}{ Taxonomic Groups } & \multicolumn{4}{|c|}{ Soil management } & \multirow{2}{*}{ Total } \\
\hline & Sp & Ssp & Tsp & Lp & \\
\hline \multicolumn{6}{|l|}{ Family Pteromalidae } \\
\hline Pteromalus sp..$^{(2)(3)}$ & $1(0.1)$ & $3(0.1)$ & $7(0.4)$ & $3(0.2)$ & $14(0.2)$ \\
\hline \multicolumn{6}{|l|}{ Suborder Apocrita - Aculeata } \\
\hline Family Apidae ${ }^{(3)(4)}$ & $1(0.1)$ & $2(0.1)$ & $2(0.1)$ & $2(0.1)$ & $7(0.1)$ \\
\hline \multicolumn{6}{|l|}{ Family Formicidae } \\
\hline Atta sexdens (Linnaeus, 1758) (2)(4) & $1(0.1)$ & - & - & $1(0.1)$ & $2(<0.1)$ \\
\hline Brachymyrmex admotus Mayr ${ }^{(2)(3)(4)}$ & $253(13.4)$ & $210(10.2)$ & $292(16.1)$ & $188(10.1)$ & $943(12.4)$ \\
\hline Brachymyrmex heeri Forel(2)(3)(4) & $34(1.8)$ & $15(0.7)$ & $19(1.0)$ & $7(0.4)$ & $75(1.0)$ \\
\hline Camponotus melanoticus Emery ${ }^{(3)(4)}$ & $1(0.1)$ & $1(<0.1)$ & - & $1(0.1)$ & $3(<0.1)$ \\
\hline Camponotus mus Roger $(3)$ & $1(0.1)$ & - & - & - & $1(<0.1)$ \\
\hline Camponotus (Myrmaphaenus) sp. $1^{(2)(3)(4)}$ & $119(6.3)$ & $128(6.2)$ & $75(4.1)$ & $98(5.3)$ & $420(5.5)$ \\
\hline Cephalotes depressus (Klug) $)^{(2)(3)(4)}$ & - & - & - & $11(0.6)$ & $11(0.1)$ \\
\hline Crematogaster prox. erecta(2)(3) & $3(0.2)$ & $4(0.2)$ & - & $1(0.1)$ & $8(0.1)$ \\
\hline Crematogaster victima Smith ${ }^{(2)(3)(4)}$ & $5(0.3)$ & $9(0.4)$ & $3(0.2)$ & $5(0.3)$ & $22(0.3)$ \\
\hline Dorymyrmex steigeri Santschi ${ }^{(3)}$ & $1(0.1)$ & - & $3(0.2)$ & - & $4(0.1)$ \\
\hline Linepithema humile Mayr ${ }^{(3)}$ & - & - & $7(0.4)$ & $33(1.8)$ & $40(0.5)$ \\
\hline Pheidole industa Santschi(3) & $13(0.7)$ & - & - & $1(0.1)$ & $14(0.2)$ \\
\hline Pseudomyrmex gracilis (Fabricius) $)^{(2)(3)(4)}$ & - & - & - & $7(0.4)$ & $7(0.1)$ \\
\hline Pseudomyrmex group Pallidus sp. $1^{(3)(4)}$ & - & - & $3(0.2)$ & $1(0.1)$ & $4(0.1)$ \\
\hline Pseudomyrmex phyllophilus (Smith) ${ }^{(2)(4)}$ & - & - & - & $2(0.1)$ & $2(<0.1)$ \\
\hline Family Vespidae ${ }^{(3)(4)}$ & $4(0.2)$ & $5(0.2)$ & $9(0.5)$ & $5(0.3)$ & $23(0.3)$ \\
\hline Order Lepidoptera (immatures) $)^{(2)(3)(4)}$ & $17(0.9)$ & $27(1.3)$ & $14(0.8)$ & $15(0.8)$ & $73(1.0)$ \\
\hline Order Mantodea (immatures) $)^{(2)(3)(4)}$ & $8(0.4)$ & $12(0.6)$ & $4(0.2)$ & $10(0.5)$ & $34(0.4)$ \\
\hline \multicolumn{6}{|l|}{ Order Neuroptera } \\
\hline \multicolumn{6}{|l|}{ Family Chrysopidae } \\
\hline Chrysoperla externa (Hagen) $)^{(2)(3)(4)}$ & $1(0.1)$ & - & $3(0.2)$ & $2(0.1)$ & $6(0.1)$ \\
\hline Immature of $C$. externa ${ }^{(2)(3)}$ & - & $1(<0.1)$ & $1(0.1)$ & $1(0.1)$ & $3(<0.1)$ \\
\hline \multicolumn{6}{|l|}{ Family Mantispidae } \\
\hline Dicromantispa gracilis (Erichson)(3) & - & - & $1(0.1)$ & $1(0.1)$ & $2(<0.1)$ \\
\hline \multicolumn{6}{|l|}{ Order Orthoptera } \\
\hline Family Acrididae (immatures) $)^{(2)(3)}$ & - & $1(<0.1)$ & $1(0.1)$ & - & $2(<0.1)$ \\
\hline Family Proscopiidae (immatures) ${ }^{(2)(4)}$ & - & $1(<0.1)$ & $2(0.1)$ & $1(0.1)$ & $4(0.1)$ \\
\hline Family Tettigoniidae (immatures) ${ }^{(2)(3)(4)}$ & $5(0.3)$ & $4(0.2)$ & $1(0.1)$ & $4(0.2)$ & $14(0.2)$ \\
\hline \multicolumn{6}{|l|}{ Order Thysanoptera } \\
\hline \multicolumn{6}{|l|}{ Family Phlaeothripidae } \\
\hline Treherniella cf. atrata De Santis ${ }^{(2)(3)(4)}$ & $1(0.1)$ & $1(<0.1)$ & - & - & $2(<0.1)$ \\
\hline \multicolumn{6}{|l|}{ Family Thripidae } \\
\hline Frankliniella insularis (Franklin)(2)(3)(4) & $17(0.9)$ & $4(0.2)$ & $18(1.0)$ & $6(0.3)$ & $45(0.6)$ \\
\hline Heliothrips haemorrhoidalis (Bouché)(4) & - & - & $2(0.1)$ & $4(0.2)$ & $6(0.1)$ \\
\hline Thrips australis (Bagnall)(2)(3)(4) & $72(3.8)$ & $111(5.4)$ & $60(3.3)$ & $119(6.4)$ & $362(4.8)$ \\
\hline Richness (S) & 94 & 90 & 96 & 99 & 150 \\
\hline Diversity of Shannon $\left(H^{\prime}\right)$ & 3.30 . & 3.30 & 3.22 & 3.27 & 3.35 \\
\hline Evenness of Pielou $\left(J^{\prime}\right)$ & 0.73 & 0.73 & 0.71 & 0.71 & 0.67 \\
\hline
\end{tabular}

(1)Absolute frequency and relative frequency (\%) in treatments: Sp - planting in small pits $(20 \times 60 \mathrm{~cm})$, Ssp - using a subsoiler with a levelling grader/shank and small pits, Tsp - using a rotary tiller and small pits, and Lp - planting in large pits $(40 \times 60 \mathrm{~cm})$. Seasons: spring ${ }^{(2)}$ - from 13 November to 10 December 2014, summer ${ }^{(3)}$ - from 30 December 2014 to 09 March 2015, and fall(4) - from 23 March to 20 May 2015. 
Among Thysanoptera species collected, Thrips australis (Bagnall) (Thripidae) is one of the four species of the genus present in Brazil; it is exotic and generally associated with Eucalyptus spp. (MONTEIRO et al., 2001). Therefore, its high frequency could be explained by the presence of plantations of eucalyptus in the area surrounding the experimental plots. The other species of thrips found were native; Heliothrips haemorrhoidalis (Bouché) feeds on a range of plants, such as citrus, persimmon and Ficus spp. (GALLO et al., 2002).

The species of potential predatory and parasitoid insects found in the areas of treatments should be highlighted, since they help the natural biological control and will be addressed in the sequence.

Among the collected predatory species belonging to Coleoptera, are those in the genus Chauliognathus (Cantharidae), as well as the ladybirds belonging to the family Coccinellidae: Cycloneda sanguinea (Linnaeus), Harmonia axyridis (Pallas) and Scymnus sp.1. Species of Chauliognathus were recorded in this investigation between November 2014 and February 2015. These insects feed on aphids and other prey (ESTRADA, 2008). The native ladybird C. sanguinea and the Asian species $H$. axyridis eat different phytophagous species such as mites, aphids, scales, psyllids, eggs and small caterpillars (CRUZ et al., 2011). In North America, adults and larvae of the Scymnus (Pullus) loewii (Mulsant) ladybird were found on pecan, where it fed on aphids and mites (REE; KNUTSON, 1997).

The species Deraeocoris nebulosus (Uhler) (Hemiptera: Miridae) is considered beneficial since it feeds on mites, small insects, insect eggs and scale insects (REE; KNUTSON, 1997). Zelus armillatus (Lepeletier \& Serville) and Zelus pedestris (Fabricius) are Reduviidae predators (ZHANG et al., 2016).

For Neuropterans, which are predatory insects, adults and immatures of Chrysoperla externa (Hagen) (Chrysopidae) and adults of Dicromantispa gracilis (Erichson) (Mantispidae) were recorded. Larvae of the species Chrysoperla carnea (Stephens) and Chrysoperla rufilabris (Burmeister) are considered predators of aphids, mites and small caterpillars, and can be used in pecan orchards for biological control (REE; KNUTSON, 1997).

For the parasitoid group, ten families were observed in the order Hymenoptera, in particular, species belonging to Braconidae and Ichneumonidae (Enfamrtidae, Eulophidae and Pteromalidae) and Platygastridae (superfamily Platygastroidae); representatives of these families are among the parasitoids most used for biological control of various agricultural and forest pests (PARRA et al., 2011). Dipteran parasitoids were also collected, and those species were not identified in the present study.

In order for a natural enemy, parasite, or predator to be considered efficient for use as a biological control agent, host's characteristics such as host specificity, pest synchronism, high biotic potential, survival ability at low populations (or an absence) and good search ability must be present (PARRA et al., 2011). Hence, to develop an Integrated Pest Management plan for pecan, we suggest future studies on the predatory and parasitoid species collected in our study, with the aim to define criteria for the natural biological control of pecan pests in Brazil, as well as the monitoring of existing and potential pest insects.

\section{CONCLUSIONS}

This study shows that soil management does not affect the diversity of arthropods in the seedling leaves of pecan, while richness is influenced by seasonality.

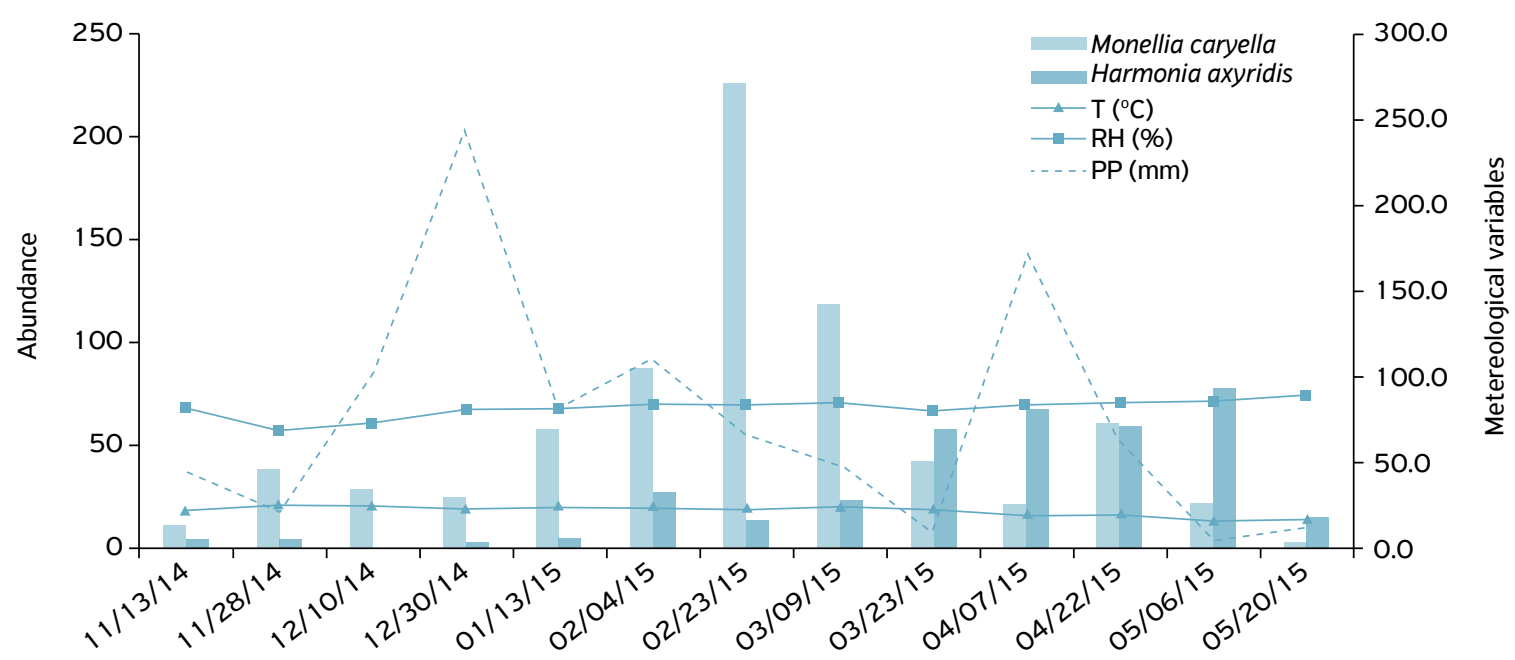

T: Temperature; RH: Relative Humidity; PP: Precipitation.

Figure 1. Population fluctuation of Monellia caryella and Harmonia axyridis specimens collected from the canopy, in a young pecan orchard under different soil managements. November 2014 to May 2015 in Santa Maria, Rio Grande do Sul, Brazil. Data of meteorological variables: Automatic Weather Station of Santa Maria (29 42' 00" S; 5342' 00" W). 
The blackmargined aphid Monellia caryella (Hemiptera: Aphididae), an exotic species introduced to Brazil, is one of the species that is dominant among pecan arthropods, and it was not influenced by different soil management practices.
Species of arthropod predators (Araneae, Coccinelidae, Reduviidae, Chrysopidae and Mantispidae) and parasitoids (Hymenoptera) are shown to be potentially natural enemies of pest insects present on pecan plants.

ACKNOWLEDGMENTS: The authors would like to thank Coordenação de Aperfeiçoamento de Pessoal de Nível Superior (CAPES) - Brazil for partial financial support received - Finance Code 001, Departamento de Diagnóstico e Pesquisa Agropecuária (DDPA) for the use of the study area, and the taxonomists who contributed to species identification: Dr. Adriano Cavalleri (Thysanoptera), Dra. Aline Barcellos Prates dos Santos and Rita d'Oliveira Lapischies (Heteroptera), Dra. Ana Paula Ott (Acari), Dr. Antonio Domingos Brescovit (Araneae), Dr. Antonio Jose Creao-Duarte (Membracidae), Dr. Caleb Califre Martins (Chrysopidae), Dra. Dalva Luiz de Queiroz and Dr. Daniel Hieronymus Burckhardt (Psylloidea), Msc. Franciele Coghetto (Collembola), Dra. Lúcia Massutti de Almeida (Coccinellidae), Dr. Pedro Giovâni da Silva (Coleoptera), Dra. Regina Célia Zonta de Carvalho (Aphididae), Dr. Renato Jose Pires Machado (Mantispidae), Dra. Silvana Lampert (Diptera), Dr. Vilmar Machado (Chauliognathus spp.) and Dr. Wilson Sampaio de Azevedo Filho (Cicadellidae).

FUNDING: This study was partial financial support by Coordenação de Aperfeiçoamento de Pessoal de Nível Superior (CAPES) - Brazil - Finance Code 001.

CONFLICTS OF INTEREST: All authors declare that they have no conflict of interest.

ETHICAL APPROVAL: Not applicable.

AVAILABILITY OF DATA AND MATERIAL: The datasets generated and/or analyzed during the current study are available from the corresponding author on reasonable request.

AUTHORS' CONTRIBUTIONS: Conceptualization: Boscardin, J.; Costa, E.C. Data curation: Boscardin, J.; Formal analysis: Boscardin, J., Fleck, M.D. Funding acquisition: Costa, E.C. Investigation: Boscardin, J.; Costa, E.C.; FLECK, M.D.; Silva, J.M. Methodology: Boscardin, J.; Costa, E.C.; FLECK, M.D.; Silva, J.M.; Karine Schoeninger, K.; Delabie, J.H.C. Project administration: Boscardin, J. Supervision: Costa, E.C. Writing - original draft: Boscardin, J. Writing - review \& editing: Boscardin, J.; Costa, E.C.; FLECK, M.D.; Silva, J.M.; Karine Schoeninger, K.; Delabie, J.H.C.

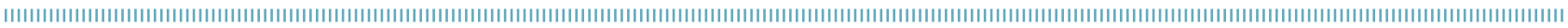
REFERENCES

ALVARES, C.A.; STAPE, J.L.; SENTELHAS, P.C.; GONÇALVES, J.L.M.; SPAROVEK, G. Köppen's climate classification map for Brazil. Meteorologische Zeitschrift, v.22, n.6, p.711-728, 2013. https://doi.org/10.1127/0941-2948/2013/0507

BILHARVA, M.G.; MARTINS, C.R.; HAMANN, J.J.; FRONZA, D.; DE MARCO, R.; MALGARIM, M.B. Pecan: from research to the Brazilian reality. Journal of Experimental Agriculture International, v.23, n.6, p. 1-16, 2018. https://doi.org/10.9734/JEAl/2018/41899

BOSCARDIN, J.; COSTA, E.C. A nogueira-pecã no Brasil: uma revisão entomológica. Ciência Florestal, v.28, n.1, p.456-468, 2018. http://dx.doi.org/10.5902/1980509831629

BOSCARDIN, J.; COSTA, E.C.; PAULUS, E.; MACHADO, D.N.; PEDRON, L.; SILVA, P.G. Crescimento de nogueira-pecã sob diferentes preparos do solo e coveamentos: coleópteros como bioindicadores. Pesquisa Florestal Brasileira, v.37, n.92, p.587596, 2017. http://dx.doi.org/10.4336/2017.pfb.37.92.1496
BOSCARDIN, J.; COSTA, E.C.; PEDRON, L.; MACHADO, D.N.; SILVA, J.M. Primer registro de chinches (Hemiptera: Coreidae y Pentatomidae) atacando frutos de nogal pecanero en Brasil. Revista Colombiana de Entomología, v.42, n. 1, p.12-15, 2016. http://dx.doi.org/10.25100/socolen.v42i 1.6663

BUMROONGSOOK, S.; HARRIS, M.K.; DEAN. D. Predation on blackmargined aphids (Homoptera: Aphididae) by spiders on pecan. Biological Control, v.2, n.1, p.15-18, 1992. https://doi. org/10.1016/1049-9644(92)90070-T

BURCKHARDT, D.; OUVRARD, D.; QUEIROZ, D.L.; PERCY, D.M. Psyllid host-plants (Hemiptera: Psylloidea): resolving a semantic problem. Florida Entomologist, v.97, n.1, p.242-246, 2014. https://doi.org/10.1653/024.097.0132

BURCKHARDT. D.; QUEIROZ, D.L.; ANDRADE, F.M.; PENTEADO, S.R.C.; IEDE, E.T.; TIERRA, A.L. Psyllid pest (Hemiptera, Psylloidea) in south american eucalypt plantations. Bulletin de La Societé Entomologic Suisse, v.72, p.1-10, 1999. 
CALL, R.E.; GIBSON, R.; KILBY, M.W. Pecan production guidelines for small orchards and home yards. University of Arizona: Arizona, United States of America. 2006. Available from: https://extension. arizona.edu/sites/extension.arizona.edu/files/pubs/az 1400. pdf. Access on: Jan. 02, 2019.

CRUZ, I.; FIGUEIREDO, M.L.C.; SILVA, R.B. Controle biológico de pragas do milho. Ciência \& Ambiente, v.43, p.165-190, 2011.

ESTRADA, C.I.N. Control Biológico de Insectos: um enfoque agroecológico. Medellín: Editorial Universidade de Antioquia, 2008.

FRONZA, D.; HAMANN, J.J.; BOTH, V.; ANESE, R.O.; MEYER, E.A. Pecan cultivation: general aspects. Ciênca Rural, v.48, n.2, p. 1 9, 2018. https://doi.org/10.1590/0103-8478cr20170179

GALLO, D.; NAKANO, O.; SILVEIRA NETO, S.; CARVALHO, R.P.L.; BAPTISTA, G.C.; BERTI FILHO, E.; PARRA, J.R.P.; ZUCCHI, R.A.; ALVES, S.B.; VENDRAMIM, J.D.; MARCHINI, L.C.; LOPES, J.R.S.; OMOTO, C. Entomologia Agrícola. Piracicaba: FEALQ, 2002.

HONIG, L. October Crop Production. Washington, D.C.: USDA, 2017.

INSTITUTO BRASILEIRO DE GEOGRAFIA E ESTATÍSTICA (IBGE). Produção Agrícola Municipal: culturas temporárias e permanentes. 2018. Available from: http://sidra.ibge.gov.br/tabela/5457. Access on: Jan. 232020.

LIAO, H.T.; HARRIS, M.K.; GILSTRAP, F.E.; MANSOUR, F. Impact of natural enemies on the blackmargined pecan aphid, Monellia caryella (Homoptera: Aphidae). Environmental Entomology, v. 14, n.2, p.122-126, 1985. https://doi.org/10.1093/ee/14.2.122

MARTINS, C.R.; FRONZA, D.; MALGARIM, M.B.; BRILHARVA, M.G.; DE MARCO, R.; HAMANN, J.J. Cultura da noz-pecã para agricultura familiar. In: WOLFF, L.F.; MEDEIROS, C.A.B. (Orgs.) Alternativas para a diversificação da agricultura familiar de base ecológica. Pelotas: Embrapa Clima Temperado, 2017.p. 65-81.
MONTEIRO, R.C.; MOUND, L.A.; ZUCCHI, R.A. Espécies de Thrips (Thysanoptera: Thripidae) no Brasil. Neotropical Entomology, v.30, n.1, p.61-63, 2001 . https://doi.org/10.1590/ S1519-566X2001000100010

PARRA, J.R.; COSTA, V.A.; PINTO, A.S. Insetos parasitoides. Ciência \& Ambiente, v.43, p. 16-36, 2011.

R DEVELOPMENT CORE TEAM. $R$ : a lenguage and environment for statistical computing. Viena, Austria: R Foundation for Statistical Computing, 2016. Available from: http://cran-r.c3sl.ufpr.br/. Access on: Jan. 30, 2017.

REE, B.; KNUTSON, A.A. Field guide to the insects and mites associated with pecan. Texas: Texas A\&M System, 1997.

ROVANI, F.F.M.; WOLLMANN, C.A. Análise sazonal e anual dos requisitos climáticos do cultivo da nogueira pecã (Carya illinoinensis) no Rio Grande do Sul. Geousp - Espaço e Tempo, v.22, n. 1, p.191-209, 2018. https://doi.org/10.11606/issn.21790892.geousp.2018.122043

SANTOS, A.; DOMENICO, F.C.; FILHO, O.P.; SOARES, R.S.; TEIXEIRA, V.A. Ocorrência de Proscopiidae em Eucalyptus spp.: análise da infestação e distribuição espacial. Pesquisa Florestal Brasileira, v.35, n.81, p.41-45, 2015. https://doi.org/10.4336/2015.pfb.35.81.706

STRECK, E.V.; KÄMPF, N.; DALMOLIN, R.S.D.; KLAMT, E.; NASCIMENTO, P.C.; SCHNEIDER, P.; GIASSON, E.; PINTO, L.F.S. Solos do Rio Grande do Sul. $2^{\text {nd }}$ ed. Porto Alegre: Emater-RS/ASCAR, 2008.

THOMPSON, T.E.; CONNER, P. Pecan. In: BADENES, M.L.; BYRNE, D.H (Orgs.). Handbook of Plant Breeding. v.8. New York: Springer Publishing, 2012. p.771-801.

ZHANG, G.; HART, E.; WEIRAUCH, C. A taxonomic monograph of the assassin bug genus Zelus Fabricius (Hemiptera: Reduviidae): 71 species based on 10,000 specimens. Biodiversity Data Journal, v.4, p.1-356, 2016. https://doi.org/10.3897/BDJ.4.e8150 